\title{
EKSPERIMENTASI MODEL PEMBELAJARAN KOOPERATIF TIPE GROUP INVESTIGATION DAN TEAM ASSISTED INDIVIDUALIZATION DENGAN PENDEKATAN CONTEXTUAL TEACHING AND LEARNING PADA POKOK BAHASANGARIS DAN SUDUT DITINJAU DARI SIKAP SISWATERHADAP MATEMATIKA KELAS VII SMP NEGERI KABUPATEN NGAWI
}

\author{
Swasti Maharani $^{1}$ Budiyono $^{2}$, Dewi Retno Sari Saputro ${ }^{3}$ \\ ${ }^{1,2,3}$ Prodi Magister Pendidikan Matematika, PPs Universitas Sebelas Maret Surakarta
}

\begin{abstract}
The objectives of this research were to find out: (1) which learning model of the GI with CTL approach, TAI with CTL approach or conventional learning results in a better learning achievement in mathematics; (2) which students attitudes toward mathematics of the positive, neutral, or negative types results in a better learning achievement in mathematics; (3) in each students attitudes toward mathematics, which learning model of the GI with CTL approach, TAI with CTL approach or conventional learning results in a better learning achievement in mathematics; and (4) in each learning model, which students attitudes toward mathematics of the positive, neutral, or negative types results in a better learning achievement in mathematics. This research used the quasi experimental research method with the factorial design of $3 \times 3$. Its population was all of the students in Grade VII of State Junior High Schools in Ngawi regency. The samples of the research were taken by using the stratified cluster random sampling technique. The data of the research were analyzed by using the unbalanced two-way analysis of variance at the significance level of 5\%. The results of this study showed that: (1) the GI and TAI with CTL approach learning models result in the same good learning achievement in mathematics, but both result in a better learning achievement in mathematics than the conventional learning model; (2) the mathematics learning achievement with positive attitudes toward mathematics was better than that with neutral and negative attitudes towards matematics, that with neutral attitude towards matematics was better than that with negative attitudes toward mathematics; (3) in each students attitudes toward mathematics type, the GI and TAI with CTL approach learning models result in the same good learning achievement in Mathematics, but both result in a better learning achievement in mathematics than the conventional learning model; (4) in each learning model, the mathematics learning achievement with positive attitudes toward mathematics was better than that with neutral and negative attitudes towards matematics, that with neutral attitude towards matematics was better than that with negative attitudes toward mathematics.

Key words: learning model, GI, TAI, conventional, CTL approach, students attitudes toward mathematics.
\end{abstract}

\section{PENDAHULUAN}

Pendidikan merupakan masalah yang penting bagi manusia karena menyangkut kelangsungan hidup manusia dan tingkat kecerdasan bangsa. Salah satu ilmu yang berperan penting dalam kehidupan adalah matematika, dimana matematika merupakan dasar komponen penting bagi bidang ilmu sains lainnya. Mahanta (2012) berpendapat sebagai berikut. 
"The study of mathematics is considered to be very important in each and every country of the world. Students are required to learn mathematics which is considered as a basic education, since the skill of mathematics computation is essential in every walk of life".

Belajar matematika dianggap sangat penting bagi setiap negara di dunia. Siswa diminta untuk belajar matematika yang dianggap sebagai pendidikan dasar, karena keterampilan perhitungan matematika sangat penting dalam setiap langkah kehidupan. Namun perkembangan pembelajaran matematika di Indonesia masih jauh dari harapan. Kualitas pendidikan Matematika di Indonesia belum meningkat secara signifikan. Prestasi siswa dalam bidang Matematika relatif rendah. Hal itu dapat dilihat dari rendahnya prestasi belajar matematika siswa di Indonesia khususnya di Kabupaten Ngawi. Berdasarkan laporan hasil nilai Ujian Nasional, SMP Negeri Kabupaten Ngawi Tahun Pelajaran 2011/2012 mendapat klasifikasi $\mathrm{C}$ dengan rata-rata 5,83 dan nilai terendah adalah 1,25. Salah satu pokok bahasan yang termasuk rendah dibandingkan dengan nilai propinsi dan nasional adalah materi garis dan sudut (Puspendik, 2012).

Sudah bukan hal baru lagi bahwa matematika dianggap sebagai salah satu pelajaran yang sulit bagi siswa. Oleh karena itu diperlukan adanya pembaharuan dalam bidang pendidikan. Salah satu pembaharuan yang dapat dilakukan adalah dengan meningkatkan kualitas pembelajaran matematika. Keberhasilan siswa dalam belajar bergantung pada cara penyajian materi pelajaran dan model pembelajaran yang digunakan oleh guru. Namun pembelajaran matematika di lapangan pada umumnya cenderung terfokus pada guru (teacher centered). Faktor yang mempengaruhi keberhasilan belajar matematika diantaranya adalah sikap siswa terhadap matematika. Menurut Borasi (dalam Mohd and Farah, 2011) "The conceptions, attitudes, and expectations of students regarding mathematics and mathematics teaching have been considered to be very significant factor underlying their school experience and achievement". Konsepsi, sikap, dan harapan siswa tentang matematika dan pembelajaran matematika telah dianggap sebagai faktor yang sangat penting yang mendasari pengalaman dan prestasi mereka di sekolah. Selanjutnya, Hoang (2008) mengemukakan "there is strong evidence of associations between students' attitudes and the learning environment". Terdapat hubungan yang kuat antara sikap siswa dan lingkungan belajar. Selain itu penelitian yang dilakukan oleh Akinsola and Olowojaiye (2008) yang mengemukakan "teachers' method of instruction in classroom is important in changing students' attitude and habits towards mathematics". Metode guru dalam penyampaian pembelajaran di kelas sangat penting dalam mengubah sikap dan kebiasaan terhadap matematika. Salah satu model pembelajaran yang dapat digunakan adalah model pembelajaran kooperatif yang mana siswa membentuk kelompok-kelompok dalam 
pembelajaran, sehingga siswa mengalami perubahan suasana belajar. Demikian juga hasil penelitian Zakaria, Chin and Daud (2010) yang mengemukakan "cooperative learning is an effective approach and can improve students' achievement in mathematics and attitude towards mathematics, which mathematics teachers need to incorporate in their teaching”. Pembelajaran kooperatif merupakan pendekatan yang efektif dan dapat meningkatkan prestasi siswa dalam matematika dan sikap terhadap matematika, yang guru matematika perlu untuk memasukkan ke dalam pembelajaran mereka. Pendekatan yang dapat digunakan adalah pendekatan CTL (Contextual Teaching and Learning). Deen and Smith (2006) berpendapat "the chances of enabling students to transfer learning from one teaching setting to another and/or to real life situations may increase when teachers use contextual teaching and learning practices". Kemungkinan yang memungkinkan siswa untuk mentransfer pelajaran dari satu pengaturan pembelajaran ke yang lain dan/atau ke situasi nyata mungkin meningkat bila guru menggunakan pembelajaran kontekstual dan praktek. Oleh karena itu penggunaan model pembelajaran kooperatif tipe GI dan TAI dengan pendekatan CTL menarik untuk diteliti.

Berdasarkan uraian yang dikemukakan di atas, tujuan yang ingin dicapai pada penelitian ini adalah untuk mengetahui: (1) manakah diantara model pembelajaran (GI dengan pendekatan CTL, TAI dengan pendekatan CTL, atau Konvensional) yang memberikan prestasi belajar matematika yang lebih baik pada pokok bahasan garis dan sudut; (2) manakah sikap siswa terhadap matematika yang memberikan prestasi belajar matematika yang lebih baik, sikap positif, netral atau negatif terhadap matematika; (3) pada masing-masing sikap siswa terhadap matematika, manakah yang memberikan prestasi belajar matematika lebih baik, model pembelajaran GI dengan pendekatan CTL, TAI dengan pendekatan CTL, atau Konvensional; (4) pada masing-masing model pembelajaran, manakah yang memberikan prestasi belajar matematika lebih baik, sikap positif, netral atau negatif terhadap matematika.

\section{METODE PENELITIAN}

Penelitian ini merupakan penelitian eksperimental semu dengan desain faktorial 3x3. Analisis data dilakukan dengan Anava dua jalan dengan sel tak sama dengan taraf signifikansi 5\%. Populasi penelitian adalah siswa kelas VII SMP Negeri se-Kabupaten Ngawi tahun pelajaran 2012/2013. Penelitian dilakukan di SMPN 1 Kwadungan, SMPN 6 Ngawi, dan SMPN 2 Geneng dengan ukuran sampel 235 siswa. Dari masing-masing sekolah diambil tiga kelas secara acak, masing-masing satu kelas eksperimen model pembelajaran GI dengan pendekatan CTL, satu kelas eksperimen model pembelajaran TAI dengan pendekatan CTL, dan satu kelas kontrol model pembelajaran Konvensional. 
Uji normalitas menggunakan metode Lilliefors dan diperoleh hasil bahwa ketiga kelompok berasal dari populasi yang berdistribusi normal. Hal tersebut dapat dilihat pada Tabel 1 berikut.

Tabel 1. Rangkuman Hasil Uji Normalitas untuk Data Nilai Kemampuan Awal Siswa Kelas VII

\begin{tabular}{ccccc}
\hline Pembelajaran & L Observasi & $L$ Kritik & Keputusan Uji & $\begin{array}{c}\text { Data } \\
\text { berdistribusi }\end{array}$ \\
\hline GI dengan pendekatan CTL & 0,0960 & 0,0997 & $H_{0}$ Diterima & Normal \\
TAI dengan pendekatan CTL & 0,0669 & 0,1010 & $H_{0}$ Diterima & Normal \\
Konvensional & 0,0704 & 0,0997 & $H_{0}$ Diterima & Normal \\
\hline
\end{tabular}

Uji homogenitas menggunakan uji Bartlett, diperoleh hasil bahwa ketiga kelompok mempunyai variansi homogen $\left(\chi^{2}\right.$ Observasi $=0,9282<5,9910=\chi^{2}$ Kritik$)$. Uji keseimbangan rataan menggunakan anava satu jalan dan diperoleh $F_{\text {obs }}=0,5879<3,0000=F_{\text {tabel }}$. Hal ini menunjukkan bahwa ketiga kelompok memiliki kemampuan awal yang sama atau seimbang.

Teknik pengumpulan data adalah: (1) metode tes; (2) metode dokumentasi; dan (3) metode angket. Instrumen penelitian terdiri atas: (1) tes prestasi belajar matematika; (2) angket sikap siswa terhadap matematika.

Variabel terikat adalah prestasi belajar matematika pada pokok bahasan garis dan sudut, sedangkan variabel bebasnya adalah model pembelajaran yang terbagi atas model pembelajaran GI dengan pendekatan CTL pada kelas eksperimen pertama, model pembelajaran TAI dengan pendekatan CTL pada kelas eksperimen kedua, dan model pembelajaran Konvensional pada kelas kontrol. Variabel bebas yang lain adalah sikap siswa terhadap matematika dengan kategori sikap positif, netral dan negatif terhadap matematika.

Uji coba instrumen dilakukan di SMPN 1 Barat dengan responden 30 siswa kelas VII. Untuk instrumen tes prestasi belajar, mengacu pada kriteria yaitu validitas isi, daya pembeda ( $\mathrm{D} \geq 0,3)$, tingkat kesukaran $(0,25 \leq \mathrm{P} \leq 0,75)$, dan reliabilitas $\left(r_{x y}>0,70\right)$. Dari 30 butir soal yang diujicobakan diperoleh 25 butir soal yang baik, sehingga dapat digunakan sebagai instrumen penelitian tes prestasi belajar matematika siswa. Untuk uji coba angket sikap siswa terhadap matematika, mengacu pada kriteria yaitu validitas isi, reliabilitas dengan rumus Alpha $\left(r_{11}>0,70\right)$ dan konsistensi internal $\left(r_{x y} \geq 0,3\right)$. Dari 30 butir angket yang diujicobakan diperoleh 26 butir angket yang baik. Uji prasyarat analisis yaitu uji normalitas dengan metode Lilliefors dan uji homogenitas dengan uji Bartlett. Diperoleh prasyarat normalitas dan homogenitas data telah terpenuhi, sehingga dapat dilakukan analisis data menggunakan anava dua jalan dengan sel tak sama dan uji 
komparasi ganda menggunakan metode Scheffe'. Uji Normalitas dan homogenitas dapat dilihat pada Tabel 2 dan Tabel 3 berikut.

Tabel 2. Rangkuman Hasil Uji Normalitas

\begin{tabular}{ccccc}
\hline Populasi Siswa & $L$ Observasi & $L$ Kritik & Keputusan Uji & $\begin{array}{c}\text { Data } \\
\text { Berdistribusi }\end{array}$ \\
\hline GI dengan pendekatan CTL & 0,0877 & 0,0997 & $\mathrm{H}_{0}$ Diterima & Normal \\
TAI dengan pendekatan & 0,0645 & 0,1010 & $\mathrm{H}_{0}$ Diterima & Normal \\
CTL & 0,0585 & 0,0997 & $\mathrm{H}_{0}$ Diterima & Normal \\
Konvensional & 0,0847 & 0,0924 & $\mathrm{H}_{0}$ Diterima & Normal \\
Sikap Positif & 0,0609 & 0,1134 & $\mathrm{H}_{0}$ Diterima & Normal \\
Sikap Netral & 0,0650 & 0,0978 & $\mathrm{H}_{0}$ Diterima & Normal \\
Sikap Negatif &
\end{tabular}

Tabel 3. Rangkuman Hasil Uji Homogenitas Variansi

\begin{tabular}{ccccc}
\hline Populasi Siswa Antar & $\chi^{2}$ Observasi & $\chi^{2}$ Kritik & Keputusan Uji & Kesimpulan \\
\hline Pembelajaran & 1,1393 & 5,9910 & $\mathrm{H}_{0}$ Diterima & Homogen \\
$\begin{array}{c}\text { Sikap Siswa Terhadap } \\
\text { Matematika }\end{array}$ & 0,5163 & 5,9910 & $\mathrm{H}_{0}$ Diterima & Homogen \\
\hline
\end{tabular}

\section{HASIL PENELITIAN DAN PEMBAHASAN}

Rangkuman hasil analisis anava dua jalan dapat dilihat pada Tabel 4 dan rangkuman komparasi ganda dapat dilihat pada Tabel 5 dan Tabel 6.

Tabel 4. Rangkuman Analisis Variansi Dua Jalan

\begin{tabular}{lcccccc}
\hline \multicolumn{1}{c}{ Sumber } & JK & $\mathrm{dk}$ & $\mathrm{RK}$ & Fobs & $\mathrm{F}$ tabel & Kesimpulan \\
\hline $\begin{array}{l}\text { Model } \\
\text { Pembelajaran (A) } \\
\text { Sikap Siswa }\end{array}$ & 2655,2694 & 2 & 1327,635 & 5,5297 & 3,0000 & $\mathrm{H}_{0 \mathrm{~A}}$ ditolak \\
$\begin{array}{l}\text { Terhadap } \\
\text { Matematika (B) }\end{array}$ & 1532,9107 & 2 & 766,4554 & 3,1924 & 3,0000 & $\mathrm{H}_{0 \mathrm{~B}}$ ditolak \\
$\begin{array}{l}\text { Interaksi (AB) } \\
\text { Galat }\end{array}$ & 1628,4599 & 4 & 407,115 & 1,6957 & 2,3700 & $\mathrm{H}_{0 \mathrm{AB}}$ diterima \\
Total & 54260,231 & 226 & 240,0895 & & & \\
\hline
\end{tabular}

Tabel 5. Rangkuman Komparasi Ganda Antar Baris

\begin{tabular}{cccc}
\hline $\mathrm{H}_{0}$ & $\mathrm{~F}_{\text {obs }}$ & $2 \mathrm{~F}_{0,05 ; 2,232}$ & Keputusan \\
\hline$\mu_{1 .}=\mu_{2 .}$ & 1,5267 & $(2)(3,00)=6,00$ & $\mathrm{H}_{0}$ diterima \\
$\mu_{2 .}=\mu_{3 .}$ & 94,3041 & $(2)(3,00)=6,00$ & $\mathrm{H}_{0}$ ditolak \\
$\mu_{1 .}=\mu_{3 .}$ & 70,7784 & $(2)(3,00)=6,00$ & $\mathrm{H}_{0}$ ditolak \\
\hline
\end{tabular}

Tabel 6. Rangkuman Komparasi Ganda Antar Kolom

\begin{tabular}{cccc}
\hline $\mathrm{H}_{0}$ & $\mathrm{~F}_{\text {obs }}$ & $2 \mathrm{~F}_{0,05 ; 2,232}$ & Keputusan \\
\hline$\mu_{\cdot 1}=\mu_{\cdot 2}$ & 21,6922 & $(2)(3,00)=6,00$ & $\mathrm{H}_{0}$ ditolak \\
$\mu_{\cdot 1}=\mu_{\cdot 3}$ & 69,7277 & $(2)(3,00)=6,00$ & $\mathrm{H}_{0}$ ditolak \\
$\mu_{\cdot 2}=\mu_{\cdot 3}$ & 8,7149 & $(2)(3,00)=6,00$ & $\mathrm{H}_{0}$ ditolak \\
\hline
\end{tabular}

Berdasarkan hasil analisis uji hipotesis pertama $\mathrm{F}_{\mathrm{obs}}=5,5297$ lebih dari $\mathrm{F}_{\text {tabel }}=$ 3,000 menunjukkan bahwa $\mathrm{H}_{0 \mathrm{~A}}$ ditolak artinya terdapat perbedaan prestasi belajar matematika siswa antara kelas model pembelajaran GI dengan pendekatan CTL, TAI dengan pendekatan CTL, dan Konvensional. Dari uji lanjut pasca anava diperoleh 
kesimpulan bahwa prestasi belajar matematika siswa dengan model pembelajaran GI dengan pendekatan CTL sama baiknya dengan siswa dengan model pembelajaran TAI dengan pendekatan CTL, tetapi lebih baik dibandingkan siswa dengan model pembelajaran Konvensional. Kesamaan prestasi belajar yang dihasilkan oleh model pembelajaran GI dengan pendekatan CTL dan TAI dengan pendekatan CTL, dimungkinkan karena kedua model pembelajaran tersebut merupakan pembelajaran kooperatif, di mana dalam proses pembelajaran siswa diarahkan untuk bekerja sama dengan teman-temannya dalam satu kelompok. Nurhadi (2004:112) berpendapat bahwa pembelajaran kooperatif adalah pendekatan pembelajaran yang berfokus pada penggunaan kelompok kecil siswa untuk bekerja sama dalam memaksimalkan kondisi belajar untuk mencapai tujuan belajar. Didukung hasil penelitian Zakaria, Chin and Daud (2010) yang mengemukakan bahwa cooperative learning is an effective approach and can improve students' achievement in mathematics and attitude towards mathematics, which mathematics teachers need to incorporate in their teaching. Pembelajaran kooperatif merupakan pendekatan yang efektif dan dapat meningkatkan prestasi siswa dalam matematika dan sikap terhadap matematika, yang guru matematika perlu untuk memasukkan ke dalam pembelajaran mereka.

Hanafiah dan Cucu Suhana (2012:67) mengatakan bahwa CTL merupakan suatu proses pembelajaran holistik yang bertujuan untuk membelajarkan peserta didik dalam memahami bahan ajar secara bermakna (meaningfull) yang berkaitan dengan konteks kehidupan nyata, baik berkaitan dengan lingkungan pribadi, agama, sosial, ekonomi maupun struktural. Oleh karena itu peserta didik memperoleh ilmu pengetahuan dan keterampilan yang dapat diaplikasikan dan ditransfer dari satu konteks permasalahan yang satu ke permasalahan yang lainnya. Sehingga siswa lebih termotivasi untuk mempelajari matematika. Oleh karena itu siswa dengan pembelajaran GI dan TAI dengan pendekatan CTL memiliki prestasi lebih baik daripada siswa dengan pembelajaran konvensional. Hal ini sejalan dengan penelitian Yuli Irfan Aliurido (2008) yang mengemukakan bahwa pembelajaran matematika dengan menggunakan model pembelajaran GI memberikan prestasi belajar yang lebih baik dibandingkan dengan pembelajaran matematika dengan menggunakan model pembelajaran tradisional (konvensional) pada materi pokok persamaan dan fungsi kuadrat.

Berdasarkan hasil analisis uji hipotesis kedua $F_{b}=3,1924>3,0000=F_{\text {tabel }}$ dan $F_{b} \in D K$ maka $H_{0} B$ ditolak. Berarti siswa dengan sikap positif, netral dan negatif terhadap matematika tidak semua prestasinya sama. Dari uji lanjut pasca anava diperoleh simpulan bahwa prestasi belajar matematika siswa dengan siswa dengan sikap positif terhadap matematika mempunyai prestasi belajar yang lebih baik dibandingkan siswa 
dengan sikap netral dan negatif terhadap matematika, siswa dengan sikap netral terhadap matematika mempunyai prestasi belajar lebih baik dibandingkan siswa dengan sikap negatif terhadap matematika. Sikap terhadap matematika merupakan sikap siswa terhadap matematika yaitu keadaan internal siswa, berupa kecenderungan atau kesiapan memberikan respon meliputi komponen kognitif, afektif dan konatif terhadap matematika atau pembelajaran matematika (Rusgianto, 2006:9). Oleh karena itu prestasi siswa dengan sikap positif terhadap matematika lebih baik daripada prestasi siswa dengan sikap netral dan negatif terhadap matematika, begitu juga prestasi siswa dengan sikap netral terhadap matematika lebih baik daripada prestasi siswa dengan sikap negatif terhadap matematika. Hal ini sejalan dengan penelitian yang dilakukan Dewi Kurniawati (2012) mengemukakan bahwa prestasi tata bahasa siswa yang memiliki sikap positif lebih baik daripada mereka yang memiliki sikap negatif.

Berdasarkan hasil analisis uji hipotesis ketiga $F_{o b s}<F_{0,05 ; 4,243}$ atau $F_{a b}=1,6957<$ $2,3700=F_{\text {tabel }}$ Nilai $F_{a b}$ tidak terletak di daerah kritik, sehingga $H_{0} A B$ dterima artinya tidak terdapat interaksi antara pembelajaran dan sikap siswa terhadap matematika terhadap prestasi belajar matematika siswa pada pokok bahasan garis dan sudut. Berdasarkan sikap siswa terhadap matematika, bahwa pada siswa dengan sikap positif, netral dan negatif terhadap matematika menunjukkan prestasi belajar matematika siswa dengan model pembelajaran kooperatif tipe GI dengan pendekatan CTL sama baiknya dengan prestasi belajar matematika siswa dengan model pembelajaran kooperatif tipe TAI dengan pendekatan CTL, tetapi lebih baik daripada prestasi belajar matematika siswa dengan pembelajaran konvensional.

Dari analisis variansi dua jalan diputuskan bahwa $\mathrm{H}_{0 \mathrm{AB}}$ diterima, sehingga tidak perlu dilakukan uji lanjut pasca analisis variansi dengan metode Scheffe' untuk analisis variansi dua jalan. Berdasarkan simpulan hipotesis pertama dan hipotesis kedua, maka dapat disimpulkan bahwa pada masing-masing model pembelajaran yaitu GI dengan pendekatan CTL, TAI dengan pendekatan CTL dan konvensional menunjukkan bahwa siswa dengan sikap positif terhadap matematika mempunyai prestasi lebih baik daripada siswa dengan sikap netral dan negatif terhadap matematika, siswa dengan sikap netral terhadap matematika mempunyai prestasi lebih baik daripada siswa dengan sikap negatif terhadap matematika.

\section{SIMPULAN DAN SARAN}

Berdasarkan hasil penelitian dan analisa data yang telah dilakukan, maka dapat disimpulkan sebagai berikut. 
1. Pada pokok bahasan garis dan sudut, prestasi belajar matematika siswa dengan model pembelajaran kooperatif tipe GI dengan pendekatan CTL sama dengan prestasi belajar matematika siswa dengan model pembelajaran kooperatif tipe TAI dengan pendekatan CTL dan lebih baik daripada prestasi belajar matematika siswa dengan pembelajaran konvensional.

2. Pada pokok bahasan garis dan sudut, prestasi belajar matematika siswa dengan sikap positif terhadap matematika lebih baik daripada prestasi belajar matematika siswa dengan sikap netral maupun negatif terhadap matematika. Prestasi belajar matematika siswa dengan sikap netral terhadap matematika lebih baik daripada prestasi belajar matematika siswa dengan sikap negatif terhadap matematika.

3. Pada pokok bahasan garis dan sudut, pada masing-masing sikap siswa terhadap matematika yaitu sikap positif, netral dan negatif, prestasi belajar matematika siswa dengan model pembelajaran kooperatif tipe GI dengan pendekatan CTL sama dengan prestasi belajar matematika siswa dengan model pembelajaran kooperatif tipe TAI dengan pendekatan CTL dan lebih baik daripada prestasi belajar matematika siswa dengan pembelajaran konvensional.

4. Pada pokok bahasan garis dan sudut, pada masing-masing pembelajaran yaitu GI dengan pendekatan CTL, TAI dengan pendekatan CTL maupun pembelajaran konvensional, prestasi belajar matematika siswa dengan sikap positif terhadap matematika lebih baik daripada prestasi belajar matematika siswa dengan sikap netral maupun negatif terhadap matematika, prestasi belajar matematika siswa dengan sikap netral terhadap matematika lebih baik daripada prestasi belajar matematika siswa dengan sikap negatif terhadap matematika.

Berdasarkan hasil penelitian guru sebaiknya memilih model pembelajaran yang paling sesuai untuk diterapkan dalam proses pembelajaran, misalnya dengan menggunakan model pembelajaran GI atau TAI dengan pendekatan CTL, karena dalam hasil penelitian menunjukkan bahwa model pembelajaran GI atau TAI dengan pendekatan CTL memberikan prestasi belajar yang lebih baik dibandingkan pembelajaran konvensional. Selain itu guru sebaiknya memperhatikan sikap masingmasing siswa terhadap matematika, karena sikap siswa terhadap matematika mempengaruhi prestasi belajar siswa, seperti yang ditunjukkan pada penelitian ini bahwa prestasi belajar siswa dengan sikap positif terhadap matematika lebih baik daripada prestasi belajar siswa dengan sikap netral maupun negatif terhadap matematika dan prestasi siswa dengan sikap netral terhadap matematika lebih baik daripada prestasi siswa dengan sikap negatif terhadap matematika. 


\section{DAFTAR PUSTAKA}

Akinsola, M. K. and Olowojaiye, F. B. 2008. Teacher Instructional Methods and Student Attitudes Towards Mathematics. International Electronic Journal of Mathematics Education.3(1):60-73

Deen, I. and Smith, B. P. 2006.Contextual Teaching Learning and Practices In The Family and Consumer Science Curriculum. Journal of Family and Consumer Sciences Education.24(1):14-27

Dewi Kurniawati. 2013. Efektivitas Menggunakan YouTube Video dalam Pengajaran Tata Bahasa Inggris Ditinjau dari Sikap Mahasiswa (Sebuah Penelitian Eksperimental di Semester I Mahasiswa Pendidikan Bahasa Inggris dari Institut Agama Islam Negeri Raden Intan Lampung pada Tahun Akademik 2012/2013).Tesis.Surakarta: PPs

Hanafiah dan Cucu Suhana.2012.Konsep Strategi Pembelajaran.Bandung:Refika Aditama

Hoang, T. N. 2008. The Effects Of Grade Level, Gender, and Ethnicity On Attitude and Learning Environment In Mathematics In High School. International Electronic Journal of Mathematics Education.3(1):47-58

Mahanta, D. 2012. Achievement in Mathematics: Effect of Gender and Positive/Negative Attitude of Students. International Journal of Theoretical \& Applied Sciences,4(2):157-163

Mohd, N. and Farah, T. 2011. The Effects of Attitude Towards Problem Solving in Mathematics Achievements. Australian Journal of Basic and Applied Sciences,5(12):1857-1862

Nurhadi.2004.Kurikulum 2004.Jakarta:PT Grasindo

Rusgianto.2006.Hubungan Antara Sikap Terhadap Matematika, Kecerdasan Emosional Dalam Interaksi Sosial Di Kelas Dengan Hasil Belajar Matematika Siswa Smp Negeri 5 Yogyakarta Tahun 2006.Makalah yang disampaikan pada Seminar Nasional Matematika dan Pendidikan Matematika 2006 dengan tema "Trend Penelitian dan Pembelajaran Matematika di Era ICT “ yang diselenggarakan pada tanggal24 Nopember 2006

Yuli Irvan Aliurido. 2008. Pembelajaran Group Investigationn (GI) Pada Materi

Pokok Persamaan dan Fungsi Kuadrat Ditinjau Dari Motivasi Belajar Siswa. Tesis. Surakarta: PPs

Zakaria, E., Chin, L. C. and Daud, M. Y. 2010. The Effects of Cooperative Learning on Students' Mathematics Achievement and Attitude towards Mathematics. Journal of Social Sciences, 6(2):272-275 